\title{
Financial literacy of the region's population and banking risks: a new approach to the analysis of the relationship
}

\author{
Ekaterina Sushko \\ Non-Commercial Foundation for Enterprise Restructuring \\ and Financial Institutions Development \\ Consultant on the information campaign in the framework \\ of implementing the Financial Literacy Development \\ Programs in the Volgograd Region \\ Volgograd, Russia \\ anisimova-job@mail.ru
}

\author{
Vasiliy Tarakanov \\ Volgograd State University \\ Professor, doctor of economic sciences, rector \\ Volgograd, Russia \\ v.tarakanov@volsu.ru
}

\begin{abstract}
One of the current challenges of the modern economy is the growth of financial risks associated with the low level of financial literacy of the population. The article analyzes data on credit, savings and insurance behavior of residents in Russian regions. By using factor analysis there were identified the groups of regions that are potentially more attractive and at the same time riskier (in terms of financial organization development). Based on the given analysis the relationship between bank risks and the financial literacy level of the population was revealed, this made possible to demonstrate the importance of accounting for the population financial behavior when making financial and management decisions about developing a regional banking network and the need to improve financial interaction with the population as well. In this regard one of the tasks being faced by the regional government is to implement programs to change the financial literacy level of the population, which can increase the regional competitiveness and ensure the sustainable development of the regional economy.
\end{abstract}

Keywords - financial literacy, factor analysis, classification of regions, competitiveness of regions, banking risks

\section{INTRODUCTION}

At the present stage the development of the Russian financial sector is associated with a number of risks - financial crises, US sanctions, license reviews and the rehabilitation of a number of large banks, panic of depositors, a low financial literacy level of the population and many others. At the same time in order to support the economy of the regions and increase their financial sustainability, significant investments and an increase in the scale of banking activity are needed. This should be done primarily through the regional expansion of financial institutions that creates the need to take into account the existing risks and influence on them.

In this regard, the financial sector entities lay special emphasis on the evaluation of the regional competitiveness which allows identifying possible risks and outlining the ways of territorial development of the banking network. The financial interaction between the population and banking structures based on ensuring a high standard of living for the population and income for the owners of the capital can be considered as the basis of a long-term strategy for the sustainable development of Russian regions. Therefore, such an analysis is also of a high priority for state and regional authorities whose goal is to attract potential investors and increase the welfare of the population within the regions. Taking into account the fact that the quality and volume of financial assets of regional banks depend on the financial situation of their clients (primarily individuals who own about $65-75 \%$ of the financial institution resources, see [1]), the attention in this question should be focused on the banking risks associated with a low financial literacy level of the population.

The Ministry of Finance of the Russian Federation Financial Education and Financial Literacy Project for the Russian Federation [2] has been implemented for several years. The positive change in the financial behavior of Russians contributes to the strengthening of household finances improving the quality of financial services and accelerating economic growth which determines the need for further work of the state and regional authorities in this direction. However, there still exist some insufficient data on how the financial literacy level of the population affects the functioning of financial sector entities. Financial organizations need to assess the effectiveness of improving the financial literacy level. This information would allow the financial sector entities to arrange more reasonable management and make financial decisions aimed at improving the credit and marketing policy in terms of interaction with population and developing the banking network in the most prosperous regions. This information would also increase the interest of 
banks in implementing programs to increase financial literacy if a positive financial or image effect was found.

The purpose of this study is to identify the relationship between banking risks and the financial literacy level of the population of the region. Accounting for the purpose, it is planned to propose a classification of regions which allows assessing the competitiveness of regions and the potential of the territorial developing the banking network.

The banking risk management topic is given a lot of attention in domestic and foreign studies. This article will consider the banking risks which are connected with interaction between banks and individuals and in many respects caused by specifics of work of a financial institution. In accordance with O. G. Kovalenko and O. E. Medvedeva [3] these risks can be divided into external and internal. External risks are related to changes in the borrower's creditworthiness, his financial insolvency (bankruptcy), claims of other creditors to repay debts, "external" fraud or, on the contrary, abuses by the borrowers themselves, etc. In addition to objective circumstances (rising unemployment, inflation, changes in legislation, etc.), the first type of risks can be caused by low level of financial literacy as well. This is manifested in the high debt load of the population, lack of a financial safety cushion among a significant part of population, paternalism and waiting for help from the state, ignorance of their own financial rights and duties, etc. One of the possible ways to neutralize these risks is to improve the financial literacy level of the population.

Internal banking risks are related to mistakes in the potential borrower's application scoring and the poor quality of the bank management (for example, weak control in the process of repaying the loan). The presence of these risks determines the need to take into account the financial literacy level of the population by banking organizations and improve scoring systems for borrowers on this basis which will reduce the probability of these problems.

This article proposes a classification of regions. This will allow, firstly, assessing the relationship between financial bank risks and the financial literacy level of the population; secondly, identifying regions that are potentially attractive and potentially riskier (in terms of developing financial organizations that offer credit, saving and insurance products to public).

\section{MATERIALS AND MethodS (MODEL)}

To classify by the method of factor analysis the statistical package "IBM SPSS Statistics" was used. Statistical data on 78 regions of Russia for 2015 by the Federal State Statistics Service [4], the Central Bank of Russia [5] and the Joint Credit Bureau [6] were used as a data set (for the purposes of comparing a number of territories were statistically merged, for example, Arkhangelsk region and Nenets Autonomous District). In this study we considered 27 indicators which characterize population saving activity (deposits attracted by credit organizations), population credit activity (debt on loans, the part of population covered by retail loans, average payment, the part of overdue accounts, the number of potential bankrupts), population insurance activity (insurance premiums and payments) and territorial features (income level of the population, participation in the project to increase financial literacy, the number of credit institutions). To achieve comparability of data all financial indicators were also recalculated per capita.

\section{RESULTS AND DISCUSSION}

The factor analysis of statistical data carried out by the author made it possible to determine four factor groups of regions (explaining $74.4 \%$ of the variance of the data set). These groups are:

1. "Depositors and borrowers" (Voronezh, Magadan, Murmansk, Nizhny Novgorod, Novgorod, Sakhalin, Tyumen, Kamchatsky, Primorsky, Khabarovsky, St. Petersburg and Leningrad regions, Sakha Republic, Chukotsky Autonomous District - 13 regions in total);

2. "Cautious borrowers" (Altai, Perm, Amur, Arkhangelsk, Bryansk, Vologda, Irkutsk, Kaluga, Kemerovo, Kurgan, Kursk, Novosibirsk, Omsk, Orenburg, Oryol, Penza, Pskov, Ryazan, Sverdlovsk, Tomsk, Tula, Ulyanovsk, Chelyabinsk regions, Jewish Autonomous oblast, Altai, Bashkortostan, Karelia, Komi, Udmurtia republics - 29 regions in total);

3. "Depositors" (Krasnodar, Stavropol, Moscow and Moscow region, Belgorod, Volgograd, Kaliningrad, Kirov, Kostroma, Lipetsk, Samara, Saratov, Smolensk, Tambov, Tver regions, Mari El, Mordovia, Tatarstan, Chechnya, Chuvashia republics - 19 regions in total);

4. "Careless borrowers" (Zabaikalsky, Krasnoyarsk, Astrakhan, Vladimir, Ivanovo, Rostov, Yaroslavl regions, Kabardino-Balkaria, Karachay-Cherkessia, Adygea, Buryatia, Dagestan, Ingushetia, Kalmykia, North Ossetia-Alania, Tyva, Khakassia republics - 17 regions in total).

Presented groups of regions have similar (correlating) characteristics. The study of them may be of interest to banking organizations that plan to expand the regional banking network or optimize existing areas of work with the population. Let us consider the key features of each group.

From the point of view of banking prospects and risks, factor group of regions No.1 "Depositors and borrowers" is the most attractive for development which is partly confirmed by the high level of presence of credit institutions ( 0.18 units per 10 thousand population, see Table I). Factor group No.1 consists of high-yield regions in which the inhabitants are active users of existing credit and savings opportunities equally. However, the high level of material 
TABLE I. Key characteristics of representatives of the factor groups in 2015

\begin{tabular}{|l|c|c|c|c|}
\hline \multicolumn{1}{|c|}{ Indicator } & \multicolumn{3}{c|}{ Average value in the group } \\
\cline { 2 - 5 } & $\mathbf{N o . 1}$ & No.2 & No.3 & No.4 \\
\hline Number of credit institutions and their branches, units per 10 thousand people & 0.18 & 0.11 & 0.11 & 0.12 \\
\hline Monthly average cash income of the population per capita; thousand rubles & 39.4 & 25.3 & 25.5 & 21.9 \\
\hline Deposits of individuals attracted by credit institutions, per capita, thousand rubles & 164.2 & 88.6 & 111.9 & 57.3 \\
\hline Insurance premiums per capita, rubles & 933 & 734 & 2876 & 116 \\
\hline $\begin{array}{l}\text { Individual debts on loans in rubles extended by credit institutions, per capita, thousand } \\
\text { rubles }\end{array}$ & 91.2 & 71.1 & \multirow{2}{*}{57.0} & \multirow{2}{*}{55.0} \\
\hline Nominal level of debt load PTI (payment-to-income) & 37.0 & 44.6 & 46.4 & 52.5 \\
\hline Average number of open loans per borrower, units & 1.76 & 1.77 & 1.64 & 1.66 \\
\hline Part of accounts with the delay of payments from the 1st day, \% & 15.5 & 16.9 & 16.6 & 24.7 \\
\hline Proportion of new cash loans to pay off old debts, \% & 46.2 & 54.3 & 51.8 & 48.4 \\
\hline Number of potential bankrupt borrowers, \% of the total number of borrowers & 1.46 & 1.04 & 1.09 & 1.62 \\
\hline Number of regions in the group, & $\mathbf{1 3}$ & $\mathbf{2 9}$ & $\mathbf{1 9}$ & $\mathbf{1 7}$ \\
\hline including the regions participating in the project to increase financial literacy & $\mathbf{0}$ & $\mathbf{3}$ & $\mathbf{7}$ & $\mathbf{0}$ \\
\hline
\end{tabular}

Источник: составлено авторами.

prosperity of borrowers entails higher financial risks (among the residents of the regions of this group, the number of potential bankrupts in comparison with groups No.2 and No.3 is higher, the level of debt load is average - 1.76 loans per borrower, the amount of debt per capita is maximum). In any case, regions included in the group have both sufficiently high competitive advantages (associated with the financial well-being of the population) and developed competitive environment which can become an obstacle to developing a number of banks (primarily small).

Factor groups No.2 and No. 3 can be considered as the second most attractive: some of them are active but cautious borrowers, others, on the contrary, are savers. At the same time, despite the rather good financial situation of their residents (monthly income is about 25 thousand rubles), the representation of financial institutions in them is significantly lower than in other groups -0.11 units per 10 thousand population (see Table I). This fact allows attributing them to regions with a high level of competitiveness and attractiveness for banking institutions.

Factor group No.3 can be considered as the most attractive from the point of view of financial institutions, it is characterized by lower bank risks and opportunities to expand the resource base of credit institutions (primarily at the expense of citizens' deposits). At the average level of material wealth, the size of deposits is inferior only to factor group No.1, the credit load and the level of delays are at the middle level. At the same time insurance products are very developed in factor group No.3 (the average insurance premium is 2876 rubles per capita which is the maximum among all groups, see. Table I), this indicates the financially literate approach of the population to managing their own financial risks.

Factor group No.2 is of interest due to the credit products development with a relatively lower level of risks for financial institutions. Residents of the "Cautious borrowers" region group are active users of loans and their material wealth is at the average level (the lending rate is maximum and equal to 1.77 loans per borrower at the average rate, the amount of debt per capita is lower only comparing to group No.1, each second loan in the group is aimed at repaying the old debt, see Table I). At the same time, the nominal level of debt load in group
No.2 is lower than in groups No.3 and No.4, the number of potential bankrupts is minimal which indicates the use of more cautious financial strategies by borrowers.

The riskiest and the least competitive of all factor groups can be considered the group No. 4 "Careless borrowers". Residents of regions in the group save money and use of insurance products least actively, they are active borrowers whose financial behavior can be called risky for banking organizations (the number of potential bankrupts is maximum, each second loan is used to repay old debt, $52.5 \%$ of the borrower's income goes to payments on loans). Despite the presented arguments, the number of credit institutions in these regions is slightly higher than in groups No.2 and No.3 $(0.12$ units per 10 thousand population, see Table I). In this regard, it is necessary to intensify the efforts of the regional authorities in terms of financial education of the population which will improve the financial stability of citizens and prevent risks associated with the close of banking organizations in their regions.

At present, there is an objective need for banks to take into account the risks associated not only with the income level of residents in different regions, but with a low level of their financial literacy as well. The findings obtained from the analysis confirm the works of Russian and foreign researchers. So, E. A. Fedorova, V. V. Nehaenko and S. E. Dovzhenko [7] empirically proved that financial literate people are less likely to allow the overdue loans but financially secure citizens are more likely to do this. In studies by P. Lunt, S. Livingstone [8] and B. Amponsah [9] the positive impact of financial literacy was demonstrated on the construction of savings strategies by the population, at the same time the level of income did not have a significant impact.

Thus, one of the ways to reduce banking risks is to assess and take into account the level of financial literacy of different territories population within the marketing and credit policies of banks, as well as the financial institutions impact on this level with the help of available resources.

\section{CONCLUSION}

One of the actual challenges of modern economy is the growth of financial risks associated with the low level of 
financial literacy of the population. A number of Russian regions, implementing state programs to change the financial behavior of citizens, have already achieved some success in improving the financial stability of households. This is confirmed by the data of population monitoring surveys (see, for example, comparative studies of NAFI [10]). The results of the study prove the positive effect that this work has on the subjects of the financial sector. Increasing the level of financial literacy of the population helps to reduce banking risks, to form a class of long-term investors and responsible consumers of financial services, to improve the financial interaction between financial institutions and the population. Hence, regions implementing programs to increase the financial literacy of their residents can be considered as more attractive (in terms of the regional banking network development). In this regard, one of the tasks of the regional authorities is to implement programs to influence the financial literacy level of the population which can increase the competitiveness of the regions and ensure the stability of the regional economy by increasing the material stability and well-being of the population.

\section{References}

[1] G.B. Korovin and E.A. Krokhina, "Complementary Institutions for Funding Regional Economies" [Komplementarnye instituty finansirovaniya regional"noi ekonomiki], Finance: Theory and Practice [Finansy: teoriya i praktika], vol. 21, issue 4, pp. 30-39, 2017.
[2] The Ministry of Finance of the Russian Federation Financial Education and Financial Literacy Project for the Russian Federation [Proekt Minfina Rossii "Sodeistvie povysheniyu urovnya finansovoi gramotnosti naseleniya i razvitiyu finansovogo obrazovaniya $v$ Rossiiskoi Federatsii']. URL: https://www.minfin.ru/ru/om/fingram/about/description.

[3] O.G. Kovalenko and O.E. Medvedeva, "Banking risks: the nature, classification" [Bankovskie riski: sushchnost', klassifikatsiya], Vector of science of Togliatti state University [Vektor nauki Tol'yattinskogo gosudarstvennogo universiteta], vol. 3, pp. 340-344, 2013.

[4] Federal state statistics service [Federal'naya sluzhba gosudarstvennoi statistiki]. Retrieved from http://www.gks.ru

[5] The Central Bank of the Russian Federation [Tsentral'nyi bank Rossiiskoi Federatsii]. Retrieved from http://www.cbr.ru

[6] Joint credit Bureau [Ob"edinennoe kreditnoe byuro]. Retrieved from http://www.bki-okb.ru

[7] E.A. Fedorova, V.V. Nekhayenko and S.E. Dovzhenko, "Influence of financial literacy of the population of the Russian Federation on behavior in the financial market (empirical estimation)" [Vliyanie finansovoi gramotnosti naseleniya RF na povedenie na finansovom rynke (empiricheskaya otsenka)], Forecasting Problems [Problemy prognozirovaniya], vol. 4, pp. 110-111, 2015.

[8] P. Lunt and S.M. Livingstone, "Mass Consumption and Personal Identity", Everyday economic experience. Buckingham: Open University Press, 1992.

[9] B. Amponsah, "Assessing the effect of financial literacy on saving behaviour: a case study of small scale miners in Manso Atwere in Amansie west district (BA Social Science)", Kwame Nkrumah University of Science and Technology, 2015.

[10] NAFI Research Centre [Analiticheskii tsentr NAFI]. Retrieved from https://nafi.ru/ 